\title{
ANALISIS KEMAMPUAN BERPIKIR KREATIF SISWA MELALUI PENERAPAN PENDEKATAN SAINTIFIK DALAM PEMBELAJARAN MATEMATIKA
}

\author{
Siti Inganah"), Marhan Taufik' ${ }^{2)}$, Hendarto Cahyono" ${ }^{3)}$, Siti Khoiruli Ummah' \\ FKIP Universitas Muhammadiyah Malang $(1,2,3,4)$ \\ Email: siti.inganah@yahoo.com $\left.{ }^{1}\right)$ \\ Email:marhan@umm.ac.id²) \\ Email: hendarto@umm.ac.id³) \\ Email: uli.mathed@yahoo.com ${ }^{4}$ )
}

\begin{abstract}
ABSTRAK
Pembelajaran matematika yang dilakukan di SMP Negeri 06 Batu masih berupa pembelajaran langsung yang membuat siswa terbatasi idenya dan tidak mengkonstruksi pengetahuan. Penerapan pendekatan saintifik kurang optimal karena baru diterapkan di sekolah tersebut. Tujuan kegiatan Lesson Study ini adalah untuk meningkatkan kemampuan berpikir kreatif siswa melalui penerapan pembelajaran saintifik. Kegiatan Lesson Study dilakukan dengan tahapan plan, do, dan see selama empat siklus. Pembuatan perangkat pembelajaran didiskusikan pada tahap plan kemudian dilaksanakan pada tahap do oleh guru model dan dievaluasi pada tahap see. Hasil kegiatan Lesson Study ini yaitu masih adanya miskonsepsi istilah variabel dan pengurangan suku aljabar oleh guru dan siswa. Selain itu, terdapat peningkatan kemampuan berpikir kreatif siswa sesuai aspek fluency, flexibility, dan originality dengan kriteria peningkatan yang baik di setiap siklus. Pendekatan saintifik diterapkan dengan sangat baik di setiap siklus.
\end{abstract}

Kata Kunci: pembelajaran saintifik, lesson study, berpikir kreatif

\begin{abstract}
Mathematics learning conducted in SMP Negeri 06 Batu is currently implementing a direct instruction, restricting the students' idea and not reconstructing the knowledge. The newly implemented scientific approach is currently not optimal at the school. The purpose of Lesson Study activities is to improve the students' ability to think creatively through the application of scientific learning. Lesson Study activities are conducted in stages: plan, do , and see in four cycles. The making of learning tools is discussed at the plan stage, executed on the do stage by the model teacher, and evaluated at the see stage. The results of this Lesson Study is finding misconceptions of variable and term rate reduction algebra by the teachers and students. In addition, there is an increase in students' ability to think creatively based on appropriate aspects of fluency, flexibility, and originality with the criteria of a good increase in each cycle. The scientific approach is applied in very well manners in every cycle.
\end{abstract}

Key word: scientific learning, lesson study, creative thinking

\section{PENDAHULUAN}

Pendekatan saintifik merupakan pendekatan yang dapat diterapkan pada Kurikulum 2013. Sekolah yang menerapkan Kurikulum 2013 harus mampu menggunakan pendekatan tersebut pada pembelajarannya. Permasalahan yang dapat disimpulkan berdasarkan diskusi dengan guru-guru matematika sebanyak empat 
orang yaitu SMP Negeri 06 Batu masih baru dalam melaksanakan kurikulum 2013 sehingga pelaksanaan dikatakan belum optimal. Beberapa pembelajaran, khususnya dalam pembelajaran matematika masih menggunakan metode yang kurang mengarah pada pendekatan saintifik. Penyajian materi matematika lebih menggunakan pembelajaran langsung (direct learning), yaitu siswa menerima informasi atau pengetahuan dari guru. Pembelajaran langsung merupakan metode pembelajaran yang efektif sehingga siswa dapat menggunakan waktunya secara efektif untuk belajar dengan bantuan guru $[1,2]$. Tetapi sisi negatifnya adalah siswa kurang mencari atau mengkonstruk pengetahuan sendiri.

Pembelajaran langsung tersebut menjadikan siswa kurang aktif dalam pembelajaran matematika. Pembelajaran lebih terpusat pada guru, yaitu guru lebih banyak menyampaikan informasi pengetahuan matematika melalui ceramah. tanya jawab, dan latihan soal. Siswa belum mendapat kesempatan untuk menkonstruk pengetahuan sendiri melalui kegiatan mengamati, mencoba, menanya, maupun mengasosiasikan. Pembelajaran seperti ini kurang mengoptimalkan penalaran siswa. Siswa kurang menggunakan kreativitas berpikir dalam proses pembelajaran, terutama dalam mengkonstruk pengetahuan matematika. Siswa hanya mampu menerapkan rumus-rumus matematika, namun tidak mengetahui asal rumus matematika. Pembelajaran lebih bersifat prosedural, siswa kurang memahami konsep matematika. Untuk meningkatkan proses pembelajaran yang mampu memfasilitasi siswa berpikir kreatif pada pendekatan saintifik dalam penerapan kurikulum 2013, dapat dilakukan melalui kegiatan lesson study.
Lesson study (jugyokenyu) adalah suatu proses sistematis yang digunakan oleh guru-guru Jepang untuk menguji keefektifan pengajarannya dalam rangka meningkatkan hasil pembelajaran [3]. Proses sistematis yang dimaksud adalah kerja guru secara kolaboratif untuk mengembangkan rencana dan perangkat pembelajaran, melakukan observasi, refleksi, dan revisi rencana pembelajaran secara bersiklus dan terus menerus. Pentingnya lesson study yaitu sebagai suatu metode pengembangan professional guru [4]. Guru yang baik adalah guru yang sedikit menggunakan usahanya tetapi hasil belajar siswanya dapat maksimal [5]. Ide yang terkandung dalam lesson study sebenarnya singkat dan sederhana, yakni jika seorang guru ingin meningkatkan pembelajaran salah satu cara yang paling jelas adalah melakukan kolaborasi dengan guru lain untuk merancang, mengamati, dan melakukan refleksi terhadap pembelajaran yang dilakukan [6]. Namun demikian dalam praktiknya ada beberapa variasi atau cara melaksanakan lesson study.

Berpikir kreatif sangat diperlukan siswa untuk belajar matematika, khususnya aljabar. Pembelajaran matematika yang menuntut siswa untuk berpikir kreatif dapat membangkitkan diskusi kelas dan komunikasi siswa. Ide-ide siswa dapat didiskusikan dan disampaikan secara berkelompok [7]. Indikator berpikir kreatif pada pembelajaran matematika meliputi tiga aspek, yaitu fluency, flexibility, dan originality [8]. Ketiga aspek ini dapat diases melalui kegiatan diskusi kelompok maupun klasikal.

\section{METODE PENELITIAN}

Metode pelaksanaan lesson study terdiri dari tahapan Plan, Do, See (Ono, Yumiko dan Ferreira, Johanna, 2010). 
Dalam pelaksanaannya, kegiatan lesson study yang dimulai dari koordinasi awal, perijinan ke sekolah hingga pelaksanaan Lesson Study sesuai tahapan Plan, Do, dan See. Kegiatan lesson study difokuskan pada pokok bahasan Aljabar kelas VIII. Untuk mendapatkan dan mengumpulkan data serta informasi yang dibutuhkan sebagai bahan analisis. Langkah kegiatan lesson study yang pertama adalah Studi Literatur. Studi literatur dilakukan untuk mengkaji lebih lanjut mengenai pelaksanaan kegiatan lesson study, pembelajaran saintifik, dan indikator berpikir kreatif. Kedua, persiapan perijinan dan pembuatan instrument observasi. Pada tahap ini, tim lesson study mendatangi sekolah untuk mengurus perijinan pelaksanaan lesson study dan melakukan kesepakatan dengan guru mata pelajaran. Tim lesson study melakukan diskusi dengan kepala sekolah tentang kondisi sekolah serta kondisi siswa secara umum. Ketiga, pelaksanaan lesson study. Pelaksanaan lesson study dilakukan sesuai tahap plan, do, dan see secara berurutan sebanyak empat siklus. Keempat, adalah Observasi Lapangan. Pada tahap observasi lapangan, tim lesson study beserta observer mengamati pembelajaran. Kelima, adalah dokumentasi. Selama pengamatan lapangan sumber data yang nantinya akan dijadikan data analisis berupa sumber data yang mendukung untuk menjawab masalah penelitian yang sudah ditetapkan. Adapun data yang akan diambil antara lain (1) hasil pekerjaan siswa secara tertulis, (2) hasil observasi dan suasana kelas selama pembelajaran berlangsung, (3) hasil catatan lapangan dari rangkaian kegiatan pembelajaran, dan (4) hasil perekaman baik berupa foto ataupun video pembelajaran. Pelaksanaan lesson study secara keseluruhan dapat dilihat pada Tabel 1.1.

\section{Tabel 1.1 Tabel Pelaksanaan Program Lesson Study}

\begin{tabular}{|c|c|c|c|c|}
\hline No. & Kegiatan & $\begin{array}{c}\text { Waktu } \\
\text { Pelaksanaan }\end{array}$ & Tempat Kegiatan & Penanggung Jawab Kegiatan \\
\hline 1 & $\begin{array}{l}\text { Penentuan lokasi Lesson } \\
\text { Study (Koordinasi awal) }\end{array}$ & Januari 2016 & $\begin{array}{l}\text { Kantor jurusan pendidikan } \\
\text { matematika }\end{array}$ & Dr. Siti Inganah, M.M., M.Pd \\
\hline 2 & $\begin{array}{l}\text { Koordinasi awal dengan } \\
\text { sekolah }\end{array}$ & 16 Mei 2016 & SMP Negeri 06 Batu & Drs. Hendarto Cahyono, M.Si \\
\hline 3 & $\begin{array}{l}\text { Koordinasi pelaksanaan } \\
\text { Lesson Study }\end{array}$ & 11 Juni 2016 & $\begin{array}{l}\text { Kantor Jurusan pendidikan } \\
\text { matematika }\end{array}$ & Drs. Marhan Taufik, M.Si \\
\hline 4 & Pelaksanaan Plan I & 21 Juli 2016 & SMP Negeri 06 Batu & Siti Khoiruli Ummah, M.Pd \\
\hline 5 & Pelaksanaan Do I & 28 Juli 2016 & SMP Negeri 06 Batu & Vera Ardiani, S.Si. \\
\hline 6 & Pelaksanaan See I & 28 Juli 2016 & SMP Negeri 06 Batu & $\begin{array}{l}\text { Juni Susilo Andung Widodo, } \\
\text { S.Pd }\end{array}$ \\
\hline 7 & Pelaksanaan Plan II & 29 Juli 2016 & SMP Negeri 06 Batu & Dr. Siti Inganah, M.M., M.Pd \\
\hline 8 & Pelaksanaan Do II & 29 Juli 2016 & SMP Negeri 06 Batu & Dra. Siti Fatikhatun Fatkhiyah \\
\hline 9 & Pelaksanaan See II & 29 Juli 2016 & SMP Negeri 06 Batu & Ayu Kurniawati, S.Pd. \\
\hline 10 & Pelaksanaan Plan III & 1 Agustus 2016 & SMP Negeri 06 Batu & Drs. Hendarto Cahyono, M.Si \\
\hline 11 & Pelaksanaan Do III & 1 Agustus 2016 & SMP Negeri 06 Batu & Dra. Siti Fatikhatun Fatkhiyah \\
\hline 12 & Pelaksanaan See III & 1 Agustus 2016 & SMP Negeri 06 Batu & $\begin{array}{l}\text { Juni Susilo Andung Widodo, } \\
\text { S.Pd }\end{array}$ \\
\hline 13 & Pelaksanaan Plan IV & 1 Agustus 2016 & SMP Negeri 06 Batu & Drs. Marhan Taufik, M.Si \\
\hline 14 & Pelaksanaan Do IV & 1 Agustus 2016 & SMP Negeri 06 Batu & Vera Ardiani, S.Si. \\
\hline 15 & Pelaksanaan See IV & 1 Agustus 2016 & SMP Negeri 06 Batu & Ayu Kurniawati, S.Pd. \\
\hline
\end{tabular}

\section{HASIL DAN PEMBAHASAN}

Kegiatan Plan I dilakukan pada Hari Kamis, Tanggal 21 Juli 2016 dengan melibatkan tiga guru matematika dan tim lesson study. Hal-hal yang dibahas pada 
kegiatan Plan I yaitu materi pembelajaran, skenario pembelajaran, instrument pembelajaran, pencapaian yang diharapkan pada pembelajaran, kelas sasaran, jadwal pelaksanaan do I, dan pemilihan guru model. Selain itu, tim lesson study mendiskusikan tentang karakteristik siswa di kelas sasaran.

Pencapaian pembelajaran aljabar yang didiskusikan yaitu peningkatan kerjasama antar anggota kelompok, peningkatan aktivitas siswa, peningkatan berpikir kreatif siswa, dan adanya pelaksanaan pembelajaran saintifik. Fokus utama pada pelaksanaan pembelajaran pertama yang disepakati yaitu peningkatan kerjasama antar anggota kelompok, peningkatan aktivitas siswa dan adanya pelaksanaan pembelajaran saintifik. Hal ini disepakati berdasarkan harapan bahwa pembelajaran saintifik akan membuat siswa aktif berdiskusi dalam kelompok.

Berdasarkan hasil diskusi, ditentukan ada empat indikator untuk mencapai tujuan utama pembelajaran, yaitu (1) keterlaksanaan pembelajaran saintifik (mengamati, mencoba, menanya, maupun mengasosiasikan), (2) aktivitas siswa, khususnya interaksi siswa dalam kelompok saat diskusi, (3) persentase anggota kelompok yang terlibat dalam interaksi , dan (4) kesesuaian antara isi interaksi dengan masalah yang didiskusikan.

Kegiatan Do I menunjukkan pembelajaran matematika belum dapat menunjukkan kemampuan berpikir kreatif. Penerapan pembelajaran saintifik belum optimal pada kegiatan menanya. Siswa masih belum dapat mengutarakan pertanyaan terkait dengan aljabar. Aktivitas siswa yang paling terlihat pada saat pembelajaran yaitu munculnya ide siswa untuk menghias hasil kerja siswa. Interaksi siswa untuk menyelesaikan kerja kelompok masih membutuhkan banyak bantuan guru.
Kegiatan See I dilaksanakan di ruang kepala sekolah dan dipimpin oleh moderator yaitu bapak Hendarto Cahyono. Kegiatan see I diikuti oleh guru model dan observer. Kegiatan diawali dengan penyampaian kesan pembelajaran oleh guru model yaitu diskusi kelompok belum berjalan dengan baik. Adanya keterbatasan waktu sehingga tidak ada kegiatan mengasosiasi atau mempresentasikan hasil kerja kelompok secara klasikal, dan banyaknya waktu yang diperlukan siswa untuk menghias kertas asturo. Setelah penyampaian kesan pembelajaran dari guru model, observer secara bergantian menyampaikan temuan-temuan selama pembelajaran berdasarkan lembar observasi dan catatan lapangan.

Observer menyampaikan hasil pembelajaran yaitu kreativitas siswa hanya muncul atau biasa diamati dari aspek hiasan pada asturo tetapi masih banyak siswa yang pasif, mencontek pekerjaan temannya, menunggu temannya menyelesaikan lembar kerja kelompok tanpa membantunya dan tidak adanya gagasan yang muncul secara mandiri untuk menyelesaikan lembar kerja kelompok. Kemudian masih ada anggota kelompok yang tidak peduli terhadap aktivitas kelompok sehingga hanya diam dan mengamati aktivitas teman-teman sekelasnya. Selain itu, pada pembelajaran belum muncul pertanyaan yang bersifat konseptual, pertanyaan paling banyak diutarakan tentang cara pengerjaan soal. Observer kedua dan ketiga menyampaikan adanya miskonsepsi tentang variabel.

Kegiatan Plan II dilakukan pada pertemuan yang sama yaitu satu jam sebelum dilaksanakannya Do II. Plan II yang merupakan alternatif penyelesaian yang dapat disusun dari hasil See I. Halhal yang menjadi bahasan diskusi tahap Plan II adalah sebagai berikut: (1) siswa 
tidak langsung diberikan instruksi berdiskusi dalam kelompok tetapi guru perlu memberikan penjelasan terkait instruksi apa yang harus dikerjakan siswa pada LKK, (2) penugasan ketua kelompok untuk bertanggungjawab atas penyelesaian tugas kelompok, (3) adanya petunjuk waktu pengerjaan dan peringatan waktu dari guru, dan adanya motivasi untuk bekerja sama antar anggota kelompok. Solusi yang ditawarkan untuk dapat meningkatkan berpikir kreatif siswa antara lain: (1) siswa tidak langsung diberikan instruksi berdiskusi dalam kelompok tetapi guru perlu memberikan penjelasan terkait instruksi apa yang harus dikerjakan siswa pada LKK, (2) siswa dimotivasi untuk mengutarakan gagasan prosedur penyelesaian soal LKK, dan (3) guru tidak memberikan petunjuk cara penyelesaian permasalahan tetapi memberikan pertanyaan yang mengarah pada jawaban benar.

Kegiatan Do II dilaksanakan pada kelas yang berbeda yaitu kelas VIII B dengan guru model yang berbeda dari $D o$ I. Hal ini dilakukan untuk memperbaiki pembelajaran pada Do I. Setiap siswa sudah duduk sesuai dengan kelompoknya masing-masing. Guru menginstruksikan agar setiap kelompok mempunyai yel-yel. Misalnya, ketika guru memanggil "Kelompok 1" maka semua anggota kelompok meneriakkan yel-yel mereka yaitu "mantap". Penunjukan ketua kelompok dilakukan dengan cara yang sama dengan pertemuan sebelumnya.

Guru model memberikan penjelasan tentang aturan selama diskusi kelompok sebagai berikut: (1) leader bertugas untuk mengatur jalannya diskusi dan bertanggungjawab atas terselesaikannya tugas kelompok, (2) kelompok yang menyelesaikan tugas kelompoknya harus meneriakkan yel-yel yang sudah disepakati setiap anggota kelompok, dan (3) setiap kali guru berteriak: "matematika" maka setiap siswa harus menjawab "menyenangkan" dan ketika guru memanggil nama kelompok tertentu, maka kelompok tersebut harus menjawab dengan yel-yelnya.

Selanjutnya guru model menjelaskan tentang aturan pengisian tabel dan mengingatkan bahwa operasi bentuk aljabar hanya dapat dilakukan pada sukusuku sejenis. Namun, permasalahan yang sama ditemukan yaitu kurang pahamnya siswa pada konsep suku sejenis. Kelompok (4) mengoperasikan bentuk aljabar yang tidak sejenis. Setiap kelompok mempunyai cara yang berbeda untuk menyelesaikan tugas kelompok. Guru kemudian membantu siswa menyelesaikan tugas kelompok hingga siswa menjawab dengan benar. Setiap kelompok berdiskusi dan menggunakan buku teks sebagai pedoman penyelesaian tugas kelompok. Setelah berdiskusi dan menempelkan hasil kerja kelompok di papan display, perwakilan setiap kelompok mengambil sticky notes untuk dituliskan komentar atau koreksi hasil diskusi kelompok lain. Kelompok yang mempunyai LKK warna yang sama bertukar perwakilan untuk saling mengoreksi hasil pekerjaannya

Kegiatan See II dilaksanakan setelah pembelajaran berlangsung di ruang kepala sekolah. Berikut adalah hal-hal penting yang dapat disimpulkan: (1) anggota kelompok mempengaruhi jalannya diskusi dan terselesaikannya LKK, (2) diperlukannya waktu yang cukup lama untuk memilah tugas kelompok berdasar warna, (3) empat dari enam kelompok (kelompok 1, 3, 5, 6) sudah dapat berdiskusi dengan baik dan saling menyampaikan pendapat, (4) ketua 
kelompok lima belum bertanggungjawab atas terselesaikannya LKK, (5) ketua kelompok belum terlalu tegas untuk menegur anggota kelompok yang tidak membantu mengerjakan tugas kelompok, (6) adanya lembar kerja individu mengakibatkan kelompok 1 membagi tugas dengan cara dua siswa menyelesaikan tugas kelompok dan tiga siswa lainnya menyelesaikan tugas individu, kelompok 1 tidak dapat mengelompokkan barang yang sejenis sehingga yang dioperasikan hanya koefisien dan jawaban akhir tidak memuat variabel, (7) kesalahan konsep variabel, yaitu variabel yang seharusnya menunjukkan kuantitas (banyaknya benda atau harga barang) tetapi dimaknai sebagai simbol dari benda yang ditunjuk.

Berdasarkan temuan pada kegiatan See II maka selanjutnya kegiatan dilanjutkan dengan kegiatan Plan III. Pada kegiatan Plan III yang bertindak sebagai moderator adalah Ibu Siti Inganah. Pada kegiatan Do I dan Do II dapat ditarik kesimpulan bahwa anggota kelompok mempengaruhi terselesaikannya tugas kelompok. Oleh karena itu, pada Do III guru mengacak kembali anggota kelompoknya. Guru juga disarankan menyiapkan LKK untuk setiap kelompok. Submateri yang dipelajari siswa masih terkait operasi aljabar tetapi kelanjutan dari operasi penjumlahan dan pengurangan yaitu perkalian dan pembagian. Guru perlu menegaskan tentang petunjuk pengerjaan LKK dan penegasan tugas ketua kelompok. Guru perlu menegaskan tentang variabel dan konsep penjumahan serta pengurangan. LKK yang dibuat guru sudah mengalami perbaikan yaitu pada penegasan variabel yang menunjukkan harga.

Tahap Do III guru menggunakan skenario pembelajaran yang sama, yaitu Think Pair dan Share. Siswa diminta untuk membaca buku teks apabila belum dapat memahami cara penyelesaian soal pada LKK. Siswa kemudian berdiskusi untuk menyelesaikan LKK. Setelah terselesaikannya LKK, siswa menempel hasil pekerjaan LKK kemudian melanjutkan pengerjaan tugas individu. Jawaban tugas individu semuanya ditempel pada kertas asturo. Salah satu perwakilan kelompok kemudian diminta untuk mempresentasikan hasil diskusi kelompoknya secara klasikal tetapi tidak ada tanggapan dari audiens.

Selanjutnya, guru melakukan review tentang kesalahan siswa saat operasi perkalian. Guru menegaskan bahwa $" 3(2 x+y)=(2 x+y) 3 "$ mempunyai hasil yang sama. Kelompok (3) mengatakan bahwa pada bentuk aljabar tidak berlaku sifat komutatif. Guru kemudian memberikan contoh bahwa " $2 \times 3=3 \times 2 "$ dan bertanya pada siswa sifat apakah yang berlaku pada kesamaan tersebut. Siswa menjawab dengan benar bahwa berlaku sifat komutatif. Setelah review, pengerjaan post test belum semuanya selesai karena masih banyak yang belum paham sehingga post test diubah menjadi pekerjaan rumah.

Berdasarkan dari kegiatan Do III maka dilanjutkan dengan kegiatan See III Hasil diskusi kegiat See III didapat beberapa kesimpulan diantaranya adalah pembelajaran sangat menyenangkan hal ini dapat terlihat bahwa siswa menikmati pembelajaran melalui diskusi kelompok. Siswa sudah mulai tertarik dengan apa yang dikerjakan. Siswa sudah benar dalam pengerjaan LKK terlebih dahulu yang diikuti dengan pengerjaan tugas individu. Ketika mengerjakan :LKK, siswa dapat berdiskusi dengan baik, memunculkan gagasan-gagasan yang berbeda satu sama lain meskipun tidak selalu benar. Pada saat pengerjaan LKK maupun tugas 
individu, siswa di kelompok (2) seringkali terlihat kurang percaya diri sehingga siswa tersebut bertanya kepada observer maupun guru. Setiap kelompok yang didatangi guru sudah memunculkan pertanyaan tentang gagasan prosedur penyelesaian.

Kelompok (2) dan (3) menganggap soal di LKK nomor (3) adalah jajar genjang sehingga luasnya dapat ditentukan dengan cara mengalikan alas dengan tinggi jajar genjang. Sedangkan kelompok (1) menganggap soal nomor (3) adalah bangun jajar genjang tetapi perhitungan luas menggunakan rumus panjang dikalikan lebar. Selain itu, hasil pengerjaan kelompok (1), (5), (6) menunjukkan kesalahan berupa perkalian satuan dengan symbol " $m$ " dengan variabel lainnya. Salah satu anggota kelompok (5) menjelaskan alasan bahwa variabel biasanya disimbolkan dengan huruf nonkapital.

Kegiatan Plan IV dilakukan berdasarkan hasil kegiatan See III maka untuk kegiatan Do IV diambahkan beberapa hal untuk memperbaiki kekurangan yang dialami pada kegiatan Do III, diantaranya adalah penekanan sifat komutatif perkalian. Alokasi waktu setiap kegiatan harus dapat diperhitungkan sehingga presentasi dari perwakilan kelompok tetap ada. Komentar yang dituliskan siswa sebagai koreksi pekerjaan kelompok dipertegas untuk fokus pada jawaban siswa bukan terkait hiasannya.

Kegiatan Do IV dilaksanakan setelah jeda istirahat pada hari yang sama dengan pelaksanaan Do III. Guru model pada kegiatan Do IV yaitu Ibu Vera di kelas VIII A. Kegiatan pendahuluan yaitu penegasan kembali konsep penjumlahan dan pengurangan serta makna istilah variabel. Guru juga menjelaskan aturan pengerjaan LKK terutama pada soal nomor (3) bahwa symbol "m" bukan merupakan variabel melainkan satuan yaitu meter. Siswa juga ditegaskan bahwa bangun yang tergambar pada LKK adalah persegi panjang. Kemudian guru menanyakan kembali rumus persegi panjang secara klasikal. Pada saat pengerjaan LKK, banyak kelompok yang menggunakan satuan ukuran panjang dan lebar untuk dioperasikan. Sehingga, siswa pada kelas yang melaksanakan Do IV mengalami kesulitan yang sama yaitu rancu antara symbol variabel dan satuan meter.

Guru kemudian meminta diskusi kelompok dimulai dengan cara pengerjaan LKK terlebih dahulu. Kemudian masingmasing anggota kelompok mengerjakan tugas individu tanpa mencontek teman lainnya. Hasil LKK dan tugas individu semuanya ditempel pada kertas asturo sehingga meminimalkan anggota kelompok yang bersantai dan tidak melakukan apapun seperti pada saat Do I.

Pada akhir pembelajaran siswa diajak untuk membuat kesimpulan mengenai operasi bentuk aljabar. Review dan kesimpulan yang dibuat tentang syarat suku aljabar yang dapat dioperasikan, makna variabel, dan sifat operasi aljabar. Siswa diberikan pekerjaan rumah sebagai umpan balik pembelajaran tentang operasi bentuk aljabar.

Hasil diskusi kegiatan See IV didapat beberapa kesimpulan diantaranya adalah pengelolan alokasi waktu pembelajaran sudah dilakukan dengan baik. Kegiatan pendahuluan yang sudah cukup baik yaitu dengan mengingat kembali materi sebelumnya dengan memberikan penegasan istilah yang digunakan selama pembelajaran. Kegiatan inti sudah cukup baik karena adanya presentasi dan koreksi pengerjaan LKK sehingga pembelajaran langsung dapat dinilai kesesuaiannya dengan tujuan pembelajaran dan konsep 
matematika yang benar. Meskipun anggota kelompok diacak setiap pertemuan, tetapi komunikasi antar siswa dalam kelompok sudah dapat diamati dengan baik. Komunikasi yang belum baik terlihat pada kelompok (6) karena komunikasi hanya dapat terjadi antar siswa perempuan. Pengerjaan LKK dan tugas individu masih dominan dilakukan oleh siswa perempuan karena tulisan siswa perempuan dianggap bagus dan dapat dibaca semua orang. Peran ketua kelompok sangat terlihat bagus. Hal ini dapat ditunjukkan dengan adanya teguran ketua kelompok bagi anggotanya yang terlihat sibuk menghias kertas asturo dan anggota kelompok yang tidak ikut berdiskusi atau membantu terselesaikannya LKK.

Berdasar hasil rekap lembar observasi di setiap siklus, diperoleh hasil pembelajaran saintifik dapat terlaksana dengan baik karena setiap tahap dapat dilaksanakan saat pembelajaran. Tahap asosiasi terlihat sangat bagus karena setiap siswa mendengarkan temannya saat presentasi dan memberikan sanggahan dan tanggapan terhadap hasil pekerjaan yang dipresentasikan. Berdasar aspek berpikir kreatif, kemampuan siswa menurun sedikit pada pertemuan keempat. Hal ini lebih khusus terdapat pada aspek pada saat guru bertanya, siswa menyampaikan gagasan. Pada pertemuan keempat, siswa berkurang kegiatan tanya-jawabnya. Walaupun mengalami penurunan, tetapi dapat dikatakan masih dalam kriteria sangat baik pada aspek kelancaran (fluency). Pada aspek fleksibilitas (flexibility), siswa juga masih berada pada kategori sangat baik. Hal ini dibuktikan dari adanya siswa yang dapat menyajikan atau mengusulkan variasi prosedur pengerjaan dan jawaban walaupun hanya beberapa kelompok [8]. Pada aspek keaslian (originality), siswa meningkat dan berada pada kategori sangat baik. Hal ini ditunjukkan dengan munculnya siswa yang mempunyai penyelesaian yang berbeda dengan teman lain dan ketegasan guru untuk meminta siswa berdiskusi dengan anggota kelompoknya bukan dengan kelompok lain [7]. Hasil rekap observasi dapat dibaca pada Tabel 1.2.

Tabel 1.2 Rekapitulasi Hasil Observasi Lesoon Study di SMPN 06 Batu

\begin{tabular}{|c|c|c|c|c|c|}
\hline \multirow{2}{*}{ No. Aspek } & \multirow{2}{*}{ Indikator } & \multirow{2}{*}{$\begin{array}{c}\text { Pertemuan } \\
1 \\
\end{array}$} & \multicolumn{3}{|c|}{ Pertemuan Pertemuan Pertemuan } \\
\hline & & & 2 & 3 & 4 \\
\hline 1 fluency & $\begin{array}{l}\text { Pada saat guru bertanya, } \\
\text { menyampaikan gagasan untuk } \\
\text { menyelesaikan masalah }\end{array}$ & $\begin{array}{l}\text { Sangat } \\
\text { baik }\end{array}$ & $\begin{array}{l}\text { Sangat } \\
\text { baik }\end{array}$ & $\begin{array}{c}\text { Sangat } \\
\text { baik }\end{array}$ & Baik \\
\hline$\overline{2}$ & $\begin{array}{l}\text { Pada saat diskusi kelompok, } \\
\text { siswa memberikan banyak saran } \\
\text { atau usul untuk menyelesaikan } \\
\text { masalah }\end{array}$ & baik & baik & $\begin{array}{c}\text { Sangat } \\
\text { baik }\end{array}$ & $\begin{array}{l}\text { Sangat } \\
\text { baik }\end{array}$ \\
\hline 3 & $\begin{array}{l}\text { Siswa menyelesaikan dan } \\
\text { menjawab permasalahan yang } \\
\text { diberikan dengan lancar dan } \\
\text { tepat waktu }\end{array}$ & baik & baik & baik & $\begin{array}{l}\text { Sangat } \\
\text { baik }\end{array}$ \\
\hline 4 flexibility & $\begin{array}{l}\text { Siswa dapat memberikan } \\
\text { gagasan untuk menyelesaikan } \\
\text { masalah yang bervariasi }\end{array}$ & baik & baik & baik & baik \\
\hline
\end{tabular}




\begin{tabular}{|c|c|c|c|c|c|c|}
\hline \multirow{2}{*}{ No. } & \multirow{2}{*}{ Aspek } & \multirow{2}{*}{ Indikator } & \multicolumn{4}{|c|}{ Pertemuan Pertemuan Pertemuan Pertemuan } \\
\hline & & & 1 & 2 & 3 & 4 \\
\hline 5 & & $\begin{array}{l}\text { Siswa dapat menyajikan atau } \\
\text { mempresentasikan konsep } \\
\text { dengan sudut pandang yang } \\
\text { berbeda dan bervariasi }\end{array}$ & baik & baik & baik & baik \\
\hline 6 & & $\begin{array}{l}\text { Siswa dapat memunculkan lebih } \\
\text { dari satu penyelesaian } \\
\text { permasalahan }\end{array}$ & baik & $\begin{array}{c}\text { Kurang } \\
\text { baik }\end{array}$ & baik & baik \\
\hline 7 & Originality & $\begin{array}{l}\text { Siswa dapat menyelesaikan } \\
\text { permasalahan dengan cara yang } \\
\text { berbeda dengan teman lainnya }\end{array}$ & baik & baik & baik & baik \\
\hline 8 & & $\begin{array}{l}\text { Siswa dapat memunculkan } \\
\text { gagasan terbaru untuk } \\
\text { menyelesaikan masalah }\end{array}$ & $\begin{array}{c}\text { Kurang } \\
\text { baik }\end{array}$ & $\begin{array}{c}\text { Kurang } \\
\text { baik }\end{array}$ & baik & baik \\
\hline
\end{tabular}

Kegiatan lesson study yang telah dilakukan sesuai dengan penelitian terdahulu (Hidayanto, Erry: 2016) yaitu pada tahap Plan guru dan tim melakukan diskusi untuk membuat perencanaan dan membahas perangkat pembelajaran yang telah dibuat sebelumnya. Tetapi, langkah kedua tidak dilaksanakan karena keterbatasan waktu sehingga langsung dilakukan langkah ketiga yaitu Tahap Do. Tahap ini dilakukan dengan cara open class sehingga pelaksanaan do II dilakukan secara langsung setelah tahap Do I. Tahap Plan II sesuai dengan (Putra, Yukon: 2010) yaitu melakukan refleksi untuk meninjau kembali pembelajaran yang dilakukan.

Kemampuan berpikir kreatif sudah sesuai dengan aspek pada penelitian sebelumnya (Amit, Miriam: 2011) dimana aspek fluency, flexibility dan originality semua indicator dapat terlaksana dengan cukup baik. Aspek flexibility mempunyai kemunculan indicator yang sangat baik karena munculnya berbagai interpretasi dalam setiap kelompok. Aspek originality kurang baik karena dimungkinkan soal yang dibuat belum menunjang keterbuakaan strategi siswa menyelesaikan permasalahan.

\section{SIMPULAN}

Berdasarkan pada hasil kegiatan lesson study pada mata pelajaran matematika materi aljabar dengan submateri operasi bentuk aljabar, maka disimpulkan peningkatan kemampuan berpikir kreatif siswa melalui penerapan pendekatan saintifik adalah sebagai berikut Pada saat kegiatan mengamati, siswa mendengarkan penjelasan dari guru sambil mengamati LKK. Pada kegiatan menanya, siswa mengalami peningkatan kemampuan bertanya di setiap siklus. Pada awalnya, siswa bertanya tentang bagaimana cara mengerjakan LKK kemudian siswa mulai memunculkan pertanyaan yang menimbulkan terjadinya miskonsepsi tentang sifat komutatif perkalian. Hal ini menunjukkan siswa sudah dapat memenuhi aspek flexibility karena menimbulkan gagasan baru dalam menyelesaikan soal. Pada saat kegiatan mencoba, siswa yang pada awalnya hanya beberapa yang menyelesaikan LKK tetapi pada pertemuan selanjutnya, setiap siswa bertanggung jawab terselesaikannya LKK. Pada saat kegiatan mengasosiasi berlangsung, siswa banyak mengutarakan gagasan dan sanggahan terhadap hasil pekerjaan temannya yang dipresentasikan. 
Siswa Kelas VIII A dan kelas VIII B di SMP Negeri 06 Batu mengalami peningkatan kemampuan berpikir kreatif berdasarkan aspek fluency, flexibility dan originality. Hal ini dapat dilihat dari hasil pengerjaan LKK. Siswa dapat memenuhi semua indikator pada setiap aspek baik secara lisan, maupun tulisan. Berdasarkan pada hasil kegiatan Lesson Study pada mata pelajaran matematika, materi Aljabar, maka disarankan: (1) mendesain pembelajaran yang lebih inovatif, (2) mendesain pembelajaran pada materi lain yang dapat menuntut kreativitas siswa, dan (3) manajemen waktu perlu disesuaikan dengan kegiatan siswa.

\section{DAFTAR PUSTAKA}

Ali Khan, Sher, (2012). Self Directed Learning in Mathematics at Secondary Level. Academic Research International Vol.2 No.2.(online) www.savap.org.pk

Amit, Miriam. (2011). Developing The Skills of Critical and Creative Thinking by Probability Teaching. Social and Behavioral Sciences Journal Vol.228, pages 1-688

Chiu. M. S. (2009). Approaches to the teaching of creative and non-creative mathematical problems. International Journal of Science and Mathematics Education. Vol. 7. 55-79.

Dawson, (2005). Encyclopedia of Education and Human Development. Vol.1. New Delhi: Pentagon Press. PP. 196-199

Hidayanto, Erry. 2009. Pelaksanaan Lesson Study di jurusan Pendidikan Matematika FMIPA UM. Publikasi Konferensi. UM: www. researchgate. net.

Ibrohim, (2012). Pengaruh Model Implementasi Lesson Study dalam Kegiatan MGMP terhadap Peningkatan
Kompetensi Guru dan Hasil Belajar Biologi Siswa. Disertasi tidak diterbitkan. Malang: PPs UM.

Ibrohim dan Syamsuri, (2008). Lesson Study (Studi pembelajaran) Model Pembinaan Pendidik secara Kolaboratif dan Berkelanjutan. (dipetik dari Program SISTEMS-JICA) Malang: FMIPA UM

Ibrohim dan Syamsuri, (2010). Lesson Study sebagai pola alternatif untuk meningkatkan efektifitas Praktik Lapangan (PPL) Mahasiswa Calon Guru. Makalah disajikan dalam Workshop Lesson study untuk mahasiswa, guru, dan dosen FMIPA Universitas Negeri Malang. Malang, 28 Februari.

Putra, Yukon. 2010. belajar dari Pembelajaran. Best Practice Lesson Study.Jakarta: Direktorat Tenaga Kependidikan. Dtjen PMPTK Kementrian Pendidikan Nasional.

Susilo, Herawati. (2010). Lesson Study Berbasis MGMP Sebagai Sarana Pengembangan Keprofesionalan Guru. Malang: Surya Pena Gemilang. 